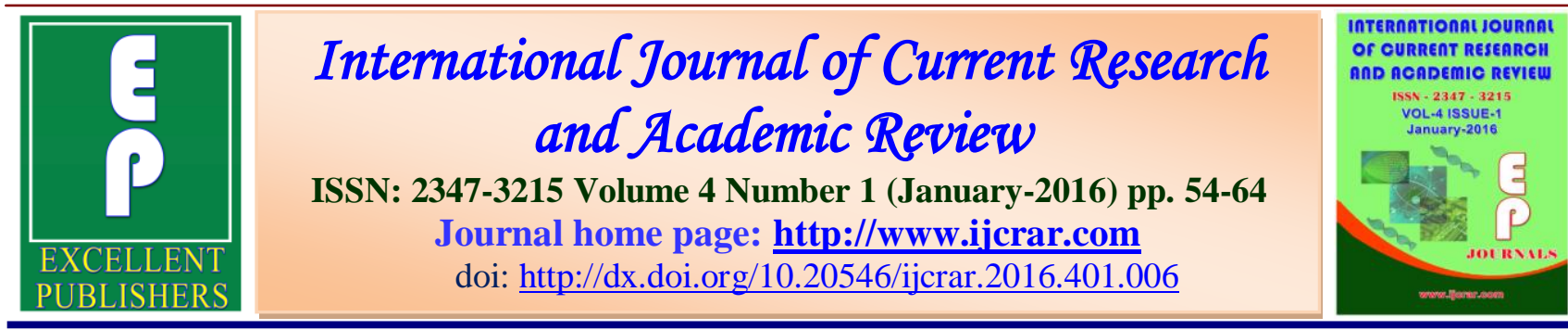

\title{
Identification of Some Iraqi Fish Parasites by using Biochemical and Molecular Protocols
}

\author{
Husain F. Hassan ${ }^{1 *}$, Dalya S.Hashim ${ }^{1}$ and Shamall M.A. Abdullah ${ }^{2}$ \\ ${ }^{1}$ Department of Biology, College of Science, University of Kirkuk, Iraq \\ ${ }^{2}$ Department of Biology, College of Education, University of Salahadin, Erbil, Iraq \\ *Corresponding author
}

\begin{tabular}{|l|l|}
\hline \multirow{2}{*}{$\begin{array}{l}\text { KEYWORDS } \\
\text { Glycogen, }\end{array}$ Lipid, } \\
DNA, \\
$\begin{array}{l}\text { Cestode, } \\
\text { Acanthocephalans, } \\
\text { Nematode, } \\
\text { marine }\end{array}$ & $\begin{array}{l}\text { Present investigation includes the quantitative estimation of protein, } \\
\text { carbohydrate, lipids and nucleic acids in fish intestinal helminthes, Khawia } \\
\text { armeniaca, Bothriocephalus acheilognathi, Senga sp., Postgangesia } \\
\text { inarmata, Procamallanus viviparous, Neoechinorhynchus iraqensis, and } \\
\text { Neoechinorhynchus zabensis. In addition, these helminthes were } \\
\text { characterized biochemically using electrophoretic isoenzyme patterns and } \\
\text { genetically using a molecular approach. The results revealed that the protein } \\
\text { and glycogen contents were low in parasites as compared to their hosts. In } \\
\text { contrast,lipids were high in parasites as compared to their hosts.DNA was } \\
\text { extracted from helminthes and used as template to amplify 5.8 S ribosomal } \\
\text { DNA primers and analysis of PCR product revealed positive band of 450 pb } \\
\text { in acanthocephalans. Isoenzyme electrophoresis revealed the presence of two } \\
\text { bands for each hexokinase and malic enzyme in acanthocephalans and one } \\
\text { band in cestodes whereas malate dehydrogenase was with two bands in } \\
\text { cestodes and with one band in acanthocephalans. }\end{array}$ \\
\hline
\end{tabular}

\section{Introduction}

The morphological simplicity and similarity of some fish helminth parasites makes the identification of closely related species extremely difficult and requires skill and experience. Consequently, any method which could quantify and qualify easily identifiable parameters would represent a great advance in fish helminth taxonomy and would permit differentiation by laboratory technicians.
Molecular classification protocols are generally tested and applied successfully to separate and distinguish several helminth species as identification and differentiation of the species based on their morphological characters is not always feasible or reliable (Zhu et al.,1998;Garcia-Varela et al., 2000). Recently, Various studies have been demonstrated that the internal transcribed spacers (ITS) and 5.8 S of ribosomal DNA 
(r DNA) sequences provide distinguishing genetic markers in fish parasitic nematodes (Shih, 2004) and acanthocephalans (GarciaVarela et al., 2005; Shih et al.,2010).

The aim of this study is to evaluate the use of biochemical analysis PCR, electrophoresis and enzyme activity determination, in order to establish a biochemical basis for the identification of the fish parasitic helminthes.

\section{Materials and Methods}

\section{Parasites}

Specimens of fishes including Luciobarus esocinus, Cyprinus carpio, Mastacembelus mastacembelus, Silurus triostegus, Liza abu and Capoeta damascina were purchased from fishermen in Kirkuk, Iraq and then transported to the laboratory where they identified, dissected and worms were washed out and collected from the alimentary tracts (Table I).

\section{Preparation of Parasites Extract}

All procedures were performed at $4^{\circ} \mathrm{C}$. The worms were minced first to aid homogenization and then suspended at 1 $\mathrm{gm} / 5 \mathrm{ml}$ in a buffer containing $50 \mathrm{mM}$ Tris$\mathrm{HCl}(\mathrm{pH} 7.5)$ and $1 \mathrm{mM}$ dithiothreitol. After homogenization in a Potter Elvehjem homogenizer, the homogenates (extracts) were sonicated three times, 30 seconds each at intervals of one minute in MSE sonicator and then centrifuged at $105,000 \mathrm{Xg}$ for 60 min. at $4^{\circ} \mathrm{C}$. The resultant supernatants were used for the electrophoretic protein analysis and as source of the standard. The carbohydrate content were estimated by Kemp et al., (1954) method and lipid were estimated by Folch et al., (1957) method. Phospholipids were determined as phosphorous using the method of Allen as given in Kates (1972). Cholestrol, triglycerides and high density lipoprotein (HDL) were estimated by lipid profil test using Reflotron Plus supplied with Reflotron Test strips.

\section{DNA Extraction}

Extraction of DNA from worms was made possible using a commercially available Bioneer Accuprep Genomic DNA Extraction Kit, Korea according to the manufacturers instructions.Briefly,200 $\mu$ of worms extracts, $20 \mu$ of proteinase $\mathrm{K}$ stock solution and $200 \mu$ of lysing buffer were pipetted in to $1.5 \mathrm{ml}$ eppendrof tube and the mixture was incubated at $37^{\circ} \mathrm{C}$ for $1 \mathrm{hr}$ and then at $70^{\circ} \mathrm{C}$ for $30 \mathrm{~min}$. Total $200 \mu$ of absolute ethanol was then added to the sample and mixed by vortexing. The mixture was then transferred to the Q1Aamp spin column and placed in a clean 2 ml.collection tube and centrifuged at $8000 \mathrm{rpm}$ for $1 \mathrm{~min}$ at room temperature.The QlAamp spin column was washed twice using $500 \mu$. of washing buffers by spinning for $1 \mathrm{~min}$. The Q1Aamp spin column was placed in a clean $1.5 \mathrm{ml}$. eppendrof tube and the DNA was eluted with $200 \mu$ of double distilled water preheated at $70{ }^{\circ} \mathrm{C}$.A maximum DNA yield was obtained by spinning at $12000 \mathrm{rpm}$ for 1 $\mathrm{min}$ at room temperature. The DNA extraction was determined by spectrophotometer at $260 \mathrm{~nm}$ wave length. Five micro liter of the suspended nucleic acid was used in the PCR amplification.

Extraction of RNA from parasitic worms was performed using the QIAmp viral RNA mini Kit (Qiagen, Valencia, CA) according to the protocol of the manufacturer. The melting temperature (Tm) in thermal denaturation of DNA was determined according to the procedure of Mandel and Marmur (1968) and the base composition guanine+ cytosine $(\mathrm{G}+\mathrm{C})$ of DNA was 
Int.J.Curr.Res.Aca.Rev.2016; 4(1): 54-64

calculated by using the formula $\% \mathrm{G}+\mathrm{C}=(\mathrm{Tm}-69.3) 2.44$.

\section{Polymerase Chain Reaction Amplification}

The PCR was initially performed using the oligonucleotide primers (forward 5' GTC GTA ACA AGG TTT CCG TA 3' and reverse 5' ATA CGA ATT TAA GTC GCC CA 3') which were previously reported to specifically amplify the digenean trematoda DNA fragments, including complete ITS1,ITS-2 and 5.8 S rRNA (Luton et al.,1992;Garcia- Varela et al.,2005).The PCR amplification was conducted using a PTC-100 thermocycler (MJ Research Inc., Waltham, MA) following the thermal profile previously used(Shih et al.,2010).

A stock buffered solution containing $250 \mu$ 10X PCR buffer, $100 \mu$ of $\mathrm{MgCl} 2,12.5 \mu$ of each dATP, dTTP, dGTP and dCTP was prepared in $1.5 \mathrm{ml}$ eppendrof tube. The primers were used at a concentration of 20 pg/ $\mu$ and double distilled water was addad to bring the volume of the stock buffer solution to $1.5 \mathrm{ml}$.Two micro liter of the primers, $5 \mu$ of the target DNA and $42 \mu$ of the stock solution were added on the 0.5 PCR tubes and mixed by vortexing. One micro liter of Taq DNA polymerase (Perkin Elmer) at a concentration of $5 \mathrm{U} / \mu$ were used. All PCR amplification reaction were carried out in a final volume of $50 \mu$. The thermal cycling profile were as follows: a 2 min initial incubation at $95^{\circ} \mathrm{C}$, followed by 40 cycles of $95^{\circ} \mathrm{C}$ for $1 \mathrm{~min}, 55^{\circ} \mathrm{C}$ for $30 \mathrm{sec}$ and $72{ }^{\circ} \mathrm{C}$ for $45 \mathrm{sec}$ and a final incubation at $72^{\circ} \mathrm{C}$ for $10 \mathrm{~min}$. Following amplification, $15 \mu$ from each PCR containing amplified products were loaded on to gels of $10 \%$ Seakem agarose (FMC Bioproduct, Rockland ME) and electrophoresed. The gels were stained with ethidium bromide and the PCR products were easily identified following visualization under UV light.

\section{Isoenzyme Electrophoresis}

Electrophoresis was performed in an LKB 2117 multiphor apparatus equipped with a LKB multitemp refrigeration unit to maintain the temperature at $4^{\circ} \mathrm{C}$ during the run. Slab $7.5 \%$ polyacrylamide gels were prepared according to Fehrnstrom and Moberg (1977) by mixing $20.5 \mathrm{ml}$ distilled water, $33 \mathrm{ml}$ gel buffer $(0.2 \mathrm{M}$ Trisglycine.pH 7.8),10.4 ml acrylamide solution (22.2 gm acrylamide, $0.6 \mathrm{gm}$ Bis per $100 \mathrm{ml}$ distilled water), $2 \mathrm{ml}$ ammonium persulphate solution $(0.07 \mathrm{M})$ and $0.1 \mathrm{ml}$ TEMED. Nine micro liter of supernatant applied to each of 20 sample slots and $1 \mu$ of bromophenol blue $(0.25 \% \mathrm{~W} / \mathrm{V})$ was added to permit visualization of the front. The electrophoresis buffer was $0.05 \mathrm{M}$ Trisglycine, $\mathrm{pH} 7.8$.

Electrophoresis was carried out at $15-20 \mathrm{~mA}$ during the first 10 minutes and then at 60 $\mathrm{mA}$ for about 4.5-5 hours.

The conditions used for developing individual zymograms are shown in Table II. The following enzymes were analysed for worms identification: Hexokinase (HK), glucose phosphate isomerase (GPI), glucose-6-phosphate dehydrogenase (G6PDH), malate dehydrogenase (MDH), malic enzyme (ME) and acid phosphatase (AcP).

\section{Results and Discussion}

The quantitative values of protein, carbohydrate and lipid compositions on wet weight basis of the fish parasites investigated are given in Tables III, IV and $\mathrm{V}$, respectively. The figures in the Tables are the mean values of three determinations. The cestode (K. armeniaca, B.acheilognathi, Senga sp. and P.inarmata) contain relatively more proteins than the acanthocephalans $(N$. 
iraqensis and N. Zabensis) and the nematode ( $P$. viviparous), whereas the acanthocephalans showed more glycogen and lipid contents than the nematode and cestodes. However, the protein and glycogen contents were low in parasites as compared to their fish hosts. In contrast, the lipid content was high in parasites as compared to their hosts. Analysis of lipids revealed the sterols, triglycerides, phospholipids and free fatty acids (Table VI). Phospholipids constituted the major lipid component of the parasites, whereas triglycerides, cholesterols and free fatty acids formed 10-18\%, 19-28\% and $18-22 \%$ respectively of the total lipids in parasites. A variety of lipoprotein conjugates have also been found in extracts of these parasitic helminth of fishes (Table VII). The quantitative determination of the total nucleic acid on fresh weight basis of parasite revealed more DNA and RNA in cestodes than in nematode and acanthocephalans (Table VIII). The base composition $(\mathrm{G}+\mathrm{C})$ has also been determined in these helminth DNA (Table VIX) and it varies from 38 to $43 \%$.

DNA purified from two acanthocephalans (N. iraqensis and N.zabensis) yielded an amplification PCR product of a similar size (450 bp) whereas the sizes of PCR products derived from the ITS and 5.8S sequences are different in length among two cestodes identified in this study. They are $550 \mathrm{bp}$ for $K$. armeniace and 600 bp for B.acheilognathi (Figure I).

Electrophoretic analysis of HK, GPI, MDH, ME, G6PDH and AcP revealed clear differences among the parasite species (Figure II and Figure III). GPI and 6PDH phenotypes presented a single band with high activity in each species. Extracts of $N$. iraqensis and $N$. zabensis revealed an $\mathrm{HK}$ and ME phenotype with two bands. The band closest to the origin exhibits weak activity. On the other hand, HK and ME phenotype showed only one band with high activity in $B$. acheilognathi, Senga sp., $K$. armeniaca and $P$. inarmata. Malate dehydrogenase $\mathrm{MDH}$ electrophoretic patterns also showed differences among the species. Neoechiorhynchus iraqensis and N.zabensis enzyme patterns consisted of single band, whereas the enzyme patterns of four cestodian species consisted of two bands, one with slightly greater mobility and the other closer to the origin. Acid phosphatase (AcP) phenotypes presented two bands with different mobility in each species.

The amount of lipid composition given are in $\mathrm{mg} / \mathrm{gm}$ wet weight and are the means from at least of three experiments. The figures in the parentheses are the amount of lipid composition as percentage to the total lipid recovered.

The present investigation provides the first powerful means for biochemical diversity amony helminth fauna from marine fish in Iraq. Chemical analysis of protein, carbohydrate, lipids, RNA and DNA indicated basic differences among analysed adult fish worms. This may have been a consequence of dynamic system, constantly synthesized and degraded. Thus, gross biochemical analysis of tissues tend to give a static impression and do not emphasize this content turnover of cellular components. The amount of protein, glycogen and lipids in the present species resembles those found in other cestodes and acanthocephalans (Fartade et al., 2011, Lanka et al., 2011).The protein content of various helminth fauna found in this study may be of value in providing rich environment for their normal development and growth, and may also be involved in other various functions including maturation of ova and protection by inhibiting host ability to detect worm's 
presence or blocking the action of host's immune response (Barrett,1981).

Glycogen is the main energy reserve in helminthes and its content depend on the nutritional state of the parasite and may fluctuates considerably during the life cycle. In cestodes, for example, there are daily fluctuations in glycogen content (Engelbrecht and Buske,1981).It is quite possible that these fish intestinal helminthes are adapted to survive in an environment where oxygen is not available and thus depends on regular supply of glycogen which can be oxidized to yield ATP.As observed from biochemical estimation, the low percentage of protein and glycogen in parasites as compared to their hosts, suggest that these worms would maintain good balance in protein content with their host and worms are quite successful in the obtaining a sufficient amount of glycogen.

Table.1 Parasites that were Collected from Gastrointestinal Tract of Fish Hosts

\begin{tabular}{|c|c|c|c|}
\hline \multirow[t]{2}{*}{ Parasites } & \multirow[t]{2}{*}{ Type } & \multicolumn{2}{|c|}{ Fish hosts } \\
\hline & & Local name & Scientific name \\
\hline Khawia armeniaca & Cestoda & Bizz & Luciobarus esocimus \\
\hline $\begin{array}{l}\text { Bothriocephalus } \\
\text { acheilognathi }\end{array}$ & Cestoda & Common Carp & Cyprinus carpio \\
\hline Senga sp. & Cestoda & Marmaritic,Salbouh Abu Sian & Mastacembelus mastacembelus \\
\hline Postgangesia inarmata & Cestoda & Asian Djirri & Silurus triostegus \\
\hline Procamallanus viviparous & Nematoda & Asian Djirri & Mastacembelus mastacemblus \\
\hline Neoechinorhynchus iragensis & Acanthocephala & Khishni,Abu Khraiza & Liza abu \\
\hline Neoechinorhynchus zabensis & Acanthocephala & Toueni & Capoeta damascina \\
\hline
\end{tabular}

Table.2.Conditions used for Developing Individual Zymograms

\begin{tabular}{|c|c|c|c|c|c|c|c|}
\hline Enzymes & Substrate & Coenzyme & Activators & $\begin{array}{l}\text { Linking } \\
\text { enzyme }\end{array}$ & $\begin{array}{l}\text { Visualisation } \\
\text { method }\end{array}$ & $\begin{array}{c}\text { Developer } \\
\text { buffer } \\
\text { 1MTris- } \\
\text { HCl,pH } 7.4\end{array}$ & $\mathrm{H}_{2} \mathrm{O}$ \\
\hline $\mathrm{HK}$ & 6mg Glucose & $\begin{array}{l}10 \mathrm{mg} \\
\text { NADP }\end{array}$ & $\begin{array}{l}25 \mathrm{mg} \mathrm{ATP} \\
43 \mathrm{mg} \\
\mathrm{MgCl}_{2} \cdot 6 \mathrm{H}_{2} \mathrm{O}\end{array}$ & $\begin{array}{c}2 \mathrm{IU} \\
\mathrm{G} 6 \mathrm{PDH}\end{array}$ & $\begin{array}{l}2 \mathrm{mg} \text { PMS } \\
4 \mathrm{mg} \text { MTT }\end{array}$ & $3 \mathrm{ml}$ & $27 \mathrm{ml}$ \\
\hline GPI & $\begin{array}{l}10 \mathrm{mg} \\
\text { Fructose-6- } \\
\text { phosphate }\end{array}$ & $\begin{array}{l}10 \mathrm{mg} \\
\mathrm{NADP}\end{array}$ & $\frac{41 \mathrm{mg}}{\mathrm{MgCl}_{2} 6 \mathrm{H}_{2} \mathrm{O}}$ & $\begin{array}{c}2 \mathrm{IU} \\
\mathrm{G} 6 \mathrm{PDH}\end{array}$ & $\begin{array}{l}2 \mathrm{mg} \text { PMS } \\
4 \mathrm{mg} \text { MTT }\end{array}$ & $8 \mathrm{ml}$ & $22 \mathrm{ml}$ \\
\hline G6PDH & $\begin{array}{l}36.5 \mathrm{mg} \\
\text { Glucose-6- } \\
\text { phosphate }\end{array}$ & $\begin{array}{l}7.5 \mathrm{mg} \\
\text { NADP }\end{array}$ & --- & --- & $\begin{array}{l}1.5 \mathrm{mg} \text { PMS } \\
1.5 \mathrm{mg} \text { MTT }\end{array}$ & $8 \mathrm{ml}$ & $16 \mathrm{ml}$ \\
\hline $\mathrm{MDH}$ & $5 \mathrm{ml}$ malic acid & $\begin{array}{l}8 \mathrm{mg} \\
\mathrm{NAD}\end{array}$ & --- & --- & $\begin{array}{c}0.5 \mathrm{mg} \text { PMS } \\
5 \mathrm{mg} \mathrm{NBT}\end{array}$ & $6 \mathrm{ml}$ & $27 \mathrm{ml}$ \\
\hline ME & $5 \mathrm{ml} \mathrm{malic} \mathrm{acid}$ & $\begin{array}{l}15 \mathrm{mg} \\
\mathrm{NADP}\end{array}$ & $\frac{5 \mathrm{mg}}{\mathrm{MgCl}_{2} 6 \mathrm{H}_{2} \mathrm{O}}$ & --- & $\begin{array}{l}1 \mathrm{mg} \text { PMS } \\
15 \mathrm{mg} \mathrm{NBT}\end{array}$ & $10 \mathrm{ml}$ & $35 \mathrm{ml}$ \\
\hline $\mathrm{AcP}^{*}$ & $\begin{array}{l}5 \mathrm{mg} 5 \text {-bromo-4- } \\
\text { chloro-3-indolyl } \\
\text { phosphate }\end{array}$ & --- & $\begin{array}{c}70 \mathrm{mg} \\
\mathrm{MgCl}_{2} 6 \mathrm{H}_{2} \mathrm{O}\end{array}$ & --- & $10 \mathrm{mg} \mathrm{NBT}$ & --- & --- \\
\hline
\end{tabular}

*The developer buffer for AcP was $30 \mathrm{ml}$ of $0.1 \mathrm{M}$ acetate buffer,pH 5.0 
Int.J.Curr.Res.Aca.Rev.2016; 4(1): 54-64

Table.3 Amount of Total Protein in the Parasitic Worms and their Hosts' Intestine

\begin{tabular}{|l|l|l|l|}
\hline Parasite & $\begin{array}{c}\text { Total protein mg/gm wet } \\
\text { weight }\end{array}$ & \multicolumn{1}{|c|}{ Host } & $\begin{array}{c}\text { Total protein mg/gm wet } \\
\text { weight }\end{array}$ \\
\hline K.armeniaca & $4.5 \pm 0.3$ & C. damascina & $10.0 \pm 1$ \\
\hline B. acheilognathi & $4.5 \pm 0.01$ & C. carpio & $10.1 \pm 2$ \\
\hline Senga sp. & $3.1 \pm 0.05$ & L. esocinus & $17.5 \pm 2$ \\
\hline P. inarmata & $3.0 \pm 0.1$ & S. triostegus & $18.2 \pm 3$ \\
\hline P. viviparous & $3.0 \pm 0.2$ & L. abu & $10.1 \pm 1$ \\
\hline N. iraqensis & $1.0 \pm 0.1$ & M. mastacembelus & $22.9 \pm 5$ \\
\hline N. zabensis & $1.0 \pm 0.04$ & & \\
\hline
\end{tabular}

The values given are means \pm SD of three experiments

Table.4 Amount of Glycogen in the Parasitic Worms and their Hosts Intestine

\begin{tabular}{|l|l|l|l|}
\hline \multicolumn{1}{|c|}{ Parasite } & \multicolumn{1}{|c|}{$\begin{array}{c}\text { Glycogen } \mathbf{~ m g / g m ~ w e t ~} \\
\text { weight }\end{array}$} & \multicolumn{1}{|c|}{ Hostycogen mg/gm wet weight } \\
\hline K. armeniaca & $3.0 \pm 0.1$ & C. damascina & $25.5 \pm 5$ \\
\hline B. acheilognathi & $3.2 \pm 0.2$ & C. carpio & $16.7 \pm 3$ \\
\hline Senga sp. & $3.0 \pm 0.2$ & L. esocinus & $23.3 \pm 5$ \\
\hline p. inarmata & $3.8 \pm 0.4$ & Silurus triostegus & $25.0 \pm 4$ \\
\hline P. viviparous & $4.8 \pm 0.6$ & L. abu & $10.3 \pm 1$ \\
\hline N. iragensis & $5.8 \pm 0.5$ & M. mastacembelus & $19.2 \pm 3$ \\
\hline N. zabensis & $6.4 \pm 1$ & & \\
\hline
\end{tabular}

Table.5 Amount of Total Lipid in the Parasitic Worms and their Hosts Intestine

\begin{tabular}{|l|l|l|c|}
\hline Parasite & $\mathbf{m g} / \mathbf{g}$ wet weight & \multicolumn{1}{|c|}{ Host } & mg/g wet weight \\
\hline K. armeniaca & $64 \pm 5$ & C. damascina & 5.29 \\
\hline B. acheilognathi & $66 \pm 3$ & C. carpio & 2.77 \\
\hline Senga sp. & $59 \pm 4$ & L. esocinus & 1.54 \\
\hline P. inarmata & $69 \pm 5$ & S. triostegus & 4.32 \\
\hline P. viviparous & $81 \pm 4$ & L. abu & 2.71 \\
\hline N. iraqensis & $90 \pm 7$ & M. mastacembelus & 2.59 \\
\hline N. zabensis & & \\
\hline
\end{tabular}

The values given are means \pm SD of three experiments

Table.6 Lipid Composition of Fish Parasitic Helminthes

\begin{tabular}{|l|l|l|l|l|l|l|l|}
\hline & $\begin{array}{l}\text { K. } \\
\text { armeniaca }\end{array}$ & $\begin{array}{l}\text { B. } \\
\text { acheilognathi }\end{array}$ & Senga sp. & P. inarmata & $\begin{array}{l}\boldsymbol{P .} \\
\text { viviparous }\end{array}$ & N. iraqensis & N. zabensis \\
\hline Total lipid & $64(100)$ & $66(100)$ & $59(100)$ & $69(100)$ & $81(100)$ & $90(100)$ & $90(100)$ \\
\hline Phospholipid & $30(47)$ & $28(43)$ & $26(44)$ & $30(43)$ & $38(47)$ & $40(44)$ & $31(34)$ \\
\hline Triglyceride & $9(14)$ & $10(15)$ & $7(12)$ & $11(16)$ & $11(13)$ & $9(10)$ & $16(18)$ \\
\hline Free fatty acid & $12(19)$ & $14(21)$ & $13(22)$ & $15(22)$ & $15(19)$ & $16(18)$ & $19(21)$ \\
\hline Cholesterol & $13(20)$ & $14(21)$ & $13(22)$ & $13(19)$ & $17(21)$ & $25(28)$ & $24(27)$ \\
\hline
\end{tabular}


Int.J.Curr.Res.Aca.Rev.2016; 4(1): 54-64

Table.7 Estimated Amount of Lipoproteins in Parasitic Worms of Fish

\begin{tabular}{|l|c|c|c|}
\hline Parasites & HDL & LDL & VLDL \\
\hline K. armeniaca & 9.5 & 1.82 & 1.79 \\
\hline B. acheilognathi & 9.1 & 2.61 & 2 \\
\hline Senga sp. & 10 & 2.06 & 1.4 \\
\hline p. inarmata & 8.2 & 2.96 & 2.24 \\
\hline P. viviparous & 11.4 & 3.48 & 2.24 \\
\hline N. iraqensis & 18.3 & 4.43 & 1.87 \\
\hline N. zabensis & 17.8 & 2.82 & 3.18 \\
\hline
\end{tabular}

The figures given are in $\mathrm{mg} / \mathrm{dl}$

Table.8 Amount of Nucleic Acids in Parasitic Worms of Fishes

\begin{tabular}{|l|l|l|l|}
\hline Parasites & DNA $\boldsymbol{\mu} \mathbf{g} / \mathbf{g}$ wet weight & RNA $\boldsymbol{\mu} \mathbf{g} / \mathbf{g}$ wet weight & \multicolumn{1}{c|}{ Total Nucleic acid } \\
\hline K. armeniaca & $2.095 \pm 0.1$ & $27.7 \pm 3$ & 29.795 \\
\hline B. acheilognathi & $2.17 \pm 0.1$ & $31.2 \pm 3$ & \\
\hline Senga sp. & $3.3 \pm 0.3$ & $15.87 \pm 2$ & 33.37 \\
\hline P. inarmata & $2.04 \pm 0.07$ & $5.66 \pm 0.4$ & 19.17 \\
\hline P. viviparous & $1.1 \pm 0.2$ & $4.15 \pm 0.5$ & 7.70 \\
\hline N. iragensis & $0.406 \pm 0.1$ & $4.00 \pm 0.3$ & 5.25 \\
\hline N. zabensis & $0.112 \pm 0.05$ & $2.94 \pm 0.05$ & 4.406 \\
\hline
\end{tabular}

The values given are mean \pm SD of three experiments

Table.9 The Guanine + Cytosine $(\mathrm{G}+\mathrm{C})$ Content of Fish Parasites DNA

\begin{tabular}{|l|l|l|}
\hline \multicolumn{1}{|c|}{ Parasite } & Tm $\left({ }^{\circ} \mathbf{C}\right)$ & $\mathbf{\%}(\mathbf{G}-\mathbf{C})$ \\
\hline Khawia armeniaca & 87 & 43 \\
\hline Bothriocephalus acheilognathi & 87 & 43 \\
\hline Senga sp. & 87 & 43 \\
\hline Postgangesia inarmata & 87 & 43 \\
\hline Procamallanus viviparous & 86 & 40 \\
\hline Neoechinorhynchus iragensis & 85 & 38 \\
\hline Neoechinorhynchus zabensis & 85 & 38 \\
\hline
\end{tabular}


Int.J.Curr.Res.Aca.Rev.2016; 4(1): 54-64

Figure.1 Amplification of DNA Extracts of Marine Fish Helminthes by PCR Reaction

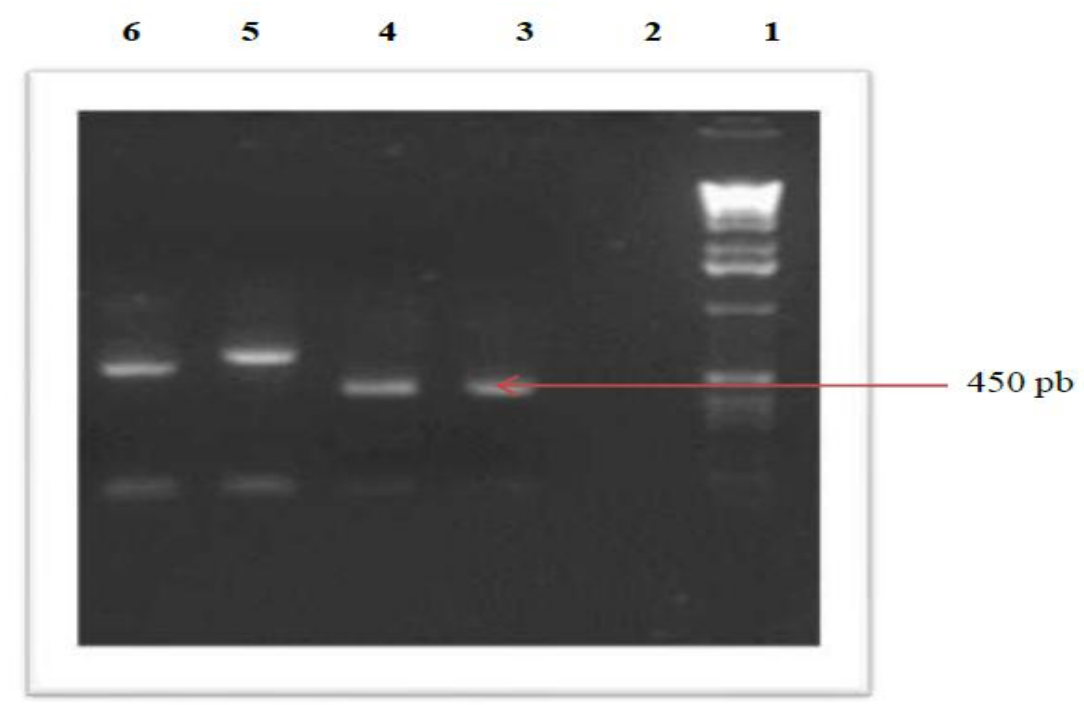

Lane 1, DNA molecular weight maker ;Lane 2, Senga sp; Lane 3, N.iraqensis ;Lane 4,N.zabensis ; Lane 5,

B.acheilognathi ;Lane 6, K.armeniaca

Figure.2 Section of Polaroid Photographs of Routine Electrophoretic Plates,Principally Carrying Enzymic Extracts of N.Iraqensis (1,2),N.Zabensis (3,4), B.Acheilognathi (5),Senga sp.

(6),K.Armeniaca (7), and P.Inarmata (8)

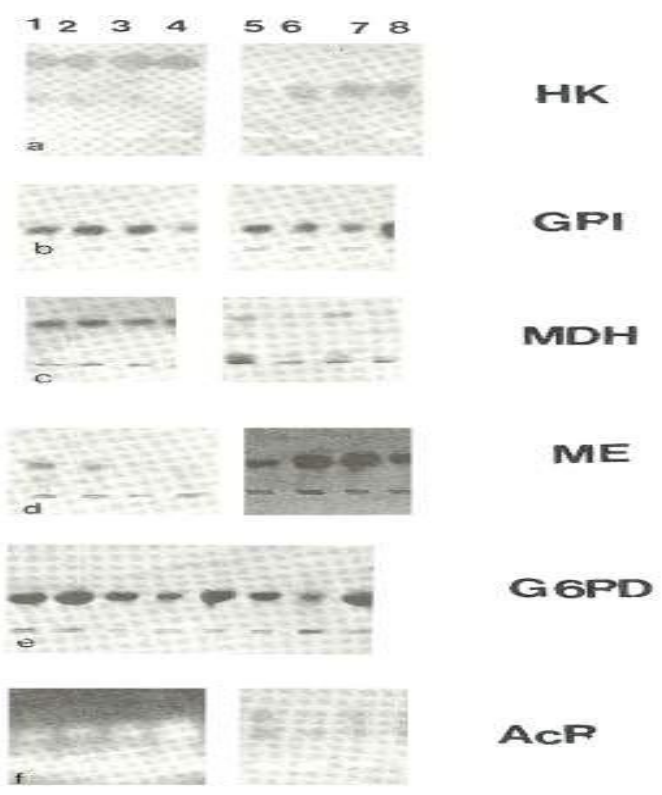

Enzymes:HK,hexokinase; GPI,glucose phosphate isomerase;MDH,malate dehydrogenase;ME,malic enzyme;G6PD,glucose-6-phosphate dehydrogenase ;ACP;acid phosphatise 
Figur.3 Comparative Electeophoretic Patterns, of N.iraqensis (1,2), N.zabensis $(3,4)$, B.acheilognathi (5),Senga sp. (6), K.armeniaca (7) and P.inarmata (8). based on the Isoenzyme Profiles of the Enzymes: HK, (hexokinase), GPI( glucose phosphate isomerase), MDH(Malate Dehydrogenase), ME(Malic Enzyme),G6PD(Glucose-6-Phosphate Dehydrogenase),ACP(acid Phosphatase)

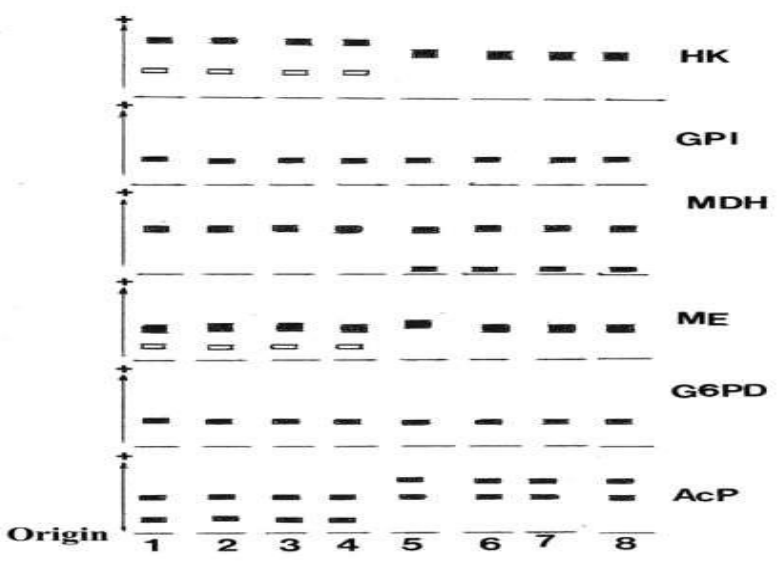

The high lipid content observed in the present fish helminthes suggest that lipids are of some special metabolic significance in these organisms. These helminthes, may rely heavily on their hosts for many lipid components either to adaptation to such a constant supply or because their environment may be unsuitable for biosynthesis. As also reported for other helminthes (Barrett et al., 1970), phospholipids constituted the major lipid components of the fish worms, possibly accumulating in the tegumentary muscle (Al-Kalak and Rahemo,2005), the remainder being triglycerides which their use in helminthes is not of much significance (Korting and Fairbairn,1972).It is quite possible that the free fatty acid may, in part, be an artefact due to hydrolysis of complex lipids during extraction and analysis. On the other hand, the sterols are of exogenous origin since anaerobic worms are unable to synthesize them (Meyer and Meyer,1972).As reported for other helminthes, the high percentage of lipid in parasites as compared to their hosts suggest that these parasites absorbing most of nourishing from host and fulfilling its need and causing hindrance in the proper development of tissue ( Fartade et al., 2011).

As might be expected, the RNA content was greater than the DNA content in the present helminthes undergoing rapid protein synthesis. The base composition of nuclear DNA is characteristic of an organism and is usually expressed as the percentage of guanosine + cytosine $(\mathrm{G}+\mathrm{C})$ bases. Thus the $\mathrm{G}+\mathrm{C}$ value for the DNA of fish helminthes was in a range (38-43\%) found to be a value similar to that of other parasitic helminthes (Barrett,1981). Due to high sensitivity, specificity, accuracy and repeatability of Tm analysis, we confirmed that this technique is useful for differentiation of the present helminthes. Because of $1.0{ }^{\circ} \mathrm{C}$ mean difference of $\mathrm{Tm}$ between species, the $\mathrm{Tm}$ ranges did not overlap, therefore these parasites could be easily and rapidly distinguished from one 
another. The accuracy of the Tm assay was confirmed by comparing these results with PCR analysis amplifying internal transcribed spacer (ITS) and $5.8 \mathrm{~S}$ r.RNA.The advantage of using PCR is that technique provide a simple, rapid, sensitive specific method for inferring phylogenetic relationships among closely related helminth species, including 1TS 1 and 1TS 2 which separate the small subunit (18S) rRNA from 5.8S and the large subunit (28S) rRNA (Garcia-Varela et al 2005).The 1TS regions can exhibit considerable differentiation between helminth species with few morphological differences (Shih et al., 2010). The results of this study were similar to previous studies in Taiwan showing differentiation of three species by rRNA sequences (Shih et al., 2010).

As far as we aware, all of the enzymes used routinely in this investigation have not been applied before to the characterization of helminth fauna of fish. None the less, almost all of the enzymes that we have used are either known to occur in the other parasitic helminthes or are to be expected from basic biochemical considerations (Waghmare and chavan, 2010).However, as our observation is based on a single, usually concentrated extract of these helminthes, it must be regarded with caution. Observing the results, there were considerable biochemical differences in electrophoretic isoenzyme patterns. Although isoenzyme electrophoresis is not considered to be the philosophers' stone' for the taxonomy of fish helminthes, refinement and simplification of the electrophoresis of selected enzymes, with appropriate standard organisms provided, might lead, eventually, to a rapid means of identifying fish helminthes in very simply equipped laboratories.
In conclusion our results are the first biochemical and electrophoretic isoenzyme studies in intestinal helminthes of fish in Iraq. In addition, the PCR assay should be used as a valuable tool to identify fish parasitic helminthes.

\section{References}

AL-Kalak,S.and Rahemo, Z.2005. Histochemistry studies of protein, lipids and DNA in Khawia grypi.J.Edu.Sci.,17,40-54.

Barrett, J.1981.Biochemistry of Parasitic Helminths. Macmillan Pub. Ltd., London and Basingstoke,308 pp.

Barrett, J.,Cain,G. and Faibairn, D. 1970. Sterols in Ascaris lumbricoides Nematoda, Macracanthorhynchus hirudinaceus Acanthocephala and Echinostoma revolutum Trematoda. J.Parasitol., 56, 1004-1008.

Engelbrecht, H. and Buske,M. 1981.Glycogen and fat in development cycle of helminthes. Angew parasitol.,22,199-204.

Fartade, A.; Jawle, S. and Borde, S. 2011. Biochemistry of ptychobothridean parasites in fresh water fish Mastacembelus armatus. Rec. Res. Sci.Tech.,3:6-8.

Fehrnstrom,H. and Moberg, V.1977.SDS and conventional polyacrylamide gel electrophoresis with LKB 2117 Multiphor.App.Note, 306.

Folch,J.,Lee,M. and Sloane,G.1957.The method of lipid estimation. J.Biol.Chem., 228,497.

Garcia-Varela,M.,de Leon,G.,Torre, Pinero,D. and Laclette, U.2005. Molecular phylogeny transcribed spacer sequences.J.Psrasitol.,91,345352.

Garcia-Varela, M., de Leon,G., Torre,P., Cummings, M.,Sarma,S and Laclette, U.2000. 
Phylogenetic relationships of Acanthocephala based on analysis of $18 \mathrm{~S}$ ribosomal RNA gene sequences.J.Mol.Evo.,50,532-540.

Kates,M.1972.Techniques of lipidology.In Work, T.S. and Work, E., Laboratory techniques in Biochemistry and Molecular Biology,Vol.3,NorthHolland Pub.C., Amsterdam.

Kemp,A.,Vankits, A.and Haljinimgen, A. 1954. A colorimetric method for the determination of glycogen in tissue.Biochem.J.,6,646-648.

Korting,W.and Fairbairn, D.1972. Anaerobic metabolism in Moniliformis dubius Acanthocephala. J.Parasitol., 58,45-50.

Lanka, L.; Patil, S. and Mohekar, A. 2011. Glycogen estimation in Senga waranensis. DCSI,5: 303-306.

Lowrey, O.; Rosebrough, N.; Farr, A. and Randall, R. 1951. Protien measurement with the folin reagent. J. Biol. Chem. 193: 265-275.

Luton,K.,Walked,D. and Blair,D.1992. Comparison of ribosomal internal transcribed spacers from two congeneric species of flukes. Mol.Biochem.Parasitol.,56,323-328.

Mandel, M. and Marmur, J. 1968. Use of ultraviolet absorbance temperature profile for determining the guanine plus cytosine content of DNA. Methods Enzym., X11:195-206.

Meyer,F. and Meyer,M.1972.Loss of fatty acid biosynthesis in flatworms,383393.In:Van Den Bossche, H., Comparative Biochemistry of Parasites. Acad press, New york.

Shih,H.2004.Parasitic helminth fauna of the cutlass fish, Trichiuris lepturus and differentiation of four anisakid nematode third stage larvae by nuclear ribosomal DNA sequences. Parasitol.Res.,93,188-195.

Shih, H., Chen,H. and Lee,C. 2010. Acanthocephalan fauna of marine fish in Taiwan and the differentiation of three species by ribosomal DNA sequences. Taiwania,55,123-127.

Waghmare, S. and Chavan,R.2010.Some quantitative studies of carbohydrate metabolites in cestode parasite of Gallus gallus domesticus. Int. J. Parasitol.Res.,2,1-4.

Zhu, X., Gasser, R., Podolska,M. and Chilton, N. 1998. Characterization of anisakid nematodes with zoonotic potential by nuclear ribosomal DNA sequences. Int.J.Parasitol.,28,19111921.

\section{How to cite this article:}

B.I. Nwachukwu. 2016. Consolidating the Dividends of Democracy at the Grassroots: Which way for Human Resources (HR) Practitioners. Int.J.Curr.Res.Aca.Rev. 4(1): 171-177. doi: http://dx.doi.org/10.20546/ijcrar.2016.401.006 